\title{
Dorota Chmielewska-Muciek*
}

\section{Kultura organizacyjna małych przedsiębiorstw działających na międzynarodowym rynku}

Streszczenie: artykuł zawiera prezentację wyników badań mających na celu zidentyfikowanie kultury organizacyjnej małych przedsiębiorstw działających na międzynarodowym rynku.

Diagnoza kultury organizacyjnej została oparta na wartościach kulturowych. Do analizy i opisu kultury organizacyjnej badanych przedsiębiorstw zastosowano badania ankietowe oparte na kwestionariuszu. W badaniach uczestniczyło 8 polskich przedsiębiorstw i 71 pracowników.

Wyniki badań wskazują, że kultura organizacyjna małych przedsiębiorstw działających na międzynarodowym rynku charakteryzuje się nastawieniem na zadania, kolektywizmem, orientacją na otoczenie, niskim kontekstem komunikacyjnym, wysoką tolerancją niepewności, statusem opartym na nadaniu, małym dystansem władzy oraz proaktywnością. Wartości kulturowe manifestowane są z niskim natężeniem, co może świadczyć o słabej kulturze organizacyjnej.

Słowa kluczowe: kultura organizacyjna, małe przedsiębiorstwa, rynek międzynarodowy.

\section{Wprowadzenie}

W procesie decyzyjnym kierownictwo przedsiębiorstwa uwzględnia i rozważa wiele czynników. Mają one charakter uwarunkowań i mogą stanowić szansę, jak i ograniczenie dla funkcjonowania organizacji. Część z nich, takie jak strategia, historia, dostępne zasoby, ma wewnętrzny charakter. Inne mają swoje źródło w otoczeniu organizacji i są od niej niezależne. Do nich kierownictwo w swoich decyzjach musi się dostosować. Gdy przedsiębiorstwo rozpoczyna działalność na zagranicznych rynkach decyzje kształtowane są nie tylko przez czynniki krajowe,

* Zakład Zarządzania, Wydział Ekonomiczny, Uniwersytet Marii Curie-Skłodowskiej w Lublinie. 
ale także biznesowe kraju goszczącego (Mead, Andrews, 2011, s. 23-25). One z kolei mogą się zasadniczo różnić od rodzimych.

Analiza uwarunkowań zagranicznych obejmuje liczne obszary. W przypadku internacjonalizacji nie chodzi tylko o region gospodarczy, ale także inne środowisko gospodarcze, polityczne, prawne, socjokulturowe i finansowe (Rothlauf, 2010, s. 14). Stanowią one wyzwanie w procesie decyzyjnym, tworząc specyficzny do rozważenia zbiór barier i obszarów problemowych. Zdaniem R. Winkel wiele charakterystyk organizacji, takich jak: posiadane przez organizację zasoby, wypracowane w jej ramach praktyki zarządzania, przyjęta forma działalności, stopień zaawansowania procesu internacjonalizacji, sytuacja na rynkach międzynarodowych i charakter interesów krajowych, nie tylko różnicuje ich istotę, ale także stopień ich przezwyciężania przez przedsiębiorstwa (Winkler, 2007, s. 78-79).

Barier, jakie występują w procesie umiędzynarodowienia działalności jest wiele. Praktyka polskich przedsiębiorstw eksportujących wskazuje, że do zasadniczych należą: bariera kulturowa i językowa, formalnoprawna oraz polityczna (Polska Agencja Wspierania Przedsiębiorczości, 2014, s. 133-140). W przypadku małych i średnich polskich przedsiębiorstw N. Daszkiewicz (2004, s. 30-31) wymienia barierę eksportową, związaną z brakiem wystarczających zasobów, osobą menedżera, marketingową i kulturę organizacyjną. We współpracy z partnerem zagranicznym może powstać bariera wzajemnego ograniczenia $\mathrm{w}$ dostępie do informacji, obawy przed utratą niezależności oraz niedopasowania partnerów szczególnie w aspekcie kulturowym (Griffin, Pustay, 1995, s. 433). Nie pogłębiając dalej wątku barier należy zaznaczyć, że zdecydowana większości opracowań na ten temat wymienia wśród nich kulturę organizacyjną.

M. Rozkwitalska (2011, s. 57-99) rozważając ten problem konkluduje, że skoro kultura organizacyjna jest elementem organizacji, to również organizacyjnym źródłem barier kulturowych. One z kolei mogą wynikać z kultury narodowej, cech przedsiębiorstwa oraz pracownika. Poza tym zmiana kultury organizacyjnej wymaga czasu, stąd niedopasowanie pod względem kulturowym może być przyczyną niepowodzenia całego przedsięwzięcia (Winkler, op. cit., s. 80). Zdaniem L. Nieżurawskiego różnice kulturowe, dzielące poszczególne kraje i przedsiębiorstwa, powinny podlegać ciągłej analizie od negocjacji począwszy, na praktykach handlowych skończywszy (Nieżurawski, Nieżurawska, 2013, s. 277). Tym bardziej, jak wynika z badań przeprowadzonych w ramach Programu Inteligentny Rozwój, zróżnicowania kulturowe są niedocenianym czynnikiem przez firmy europejskie, co w perspektywie współpracy z krajami azjatyckimi i afrykańskimi może się okazać niezwykle uciążliwą 
barierą eksportową (Wójcik, 2013, s. 1). Stąd istotnym zagadnieniem jest poznanie kultury organizacyjnej, aby kierownictwo było świadome na ile, z punktu różnic kulturowych, może ona wspierać proces internacjonalizacji przedsiębiorstwa.

Artykuł prezentuje wyniki badań dotyczące kultury organizacyjnej małych przedsiębiorstw działających w skali międzynarodowej, a jej identyfikacja została oparta na wartościach kulturowych, takich jak: nastawienie na ludzi vs na zadania, mały vs duży dystans władzy, indywidualizm vs kolektywizm, wysokie vs niskie unikanie niepewności, niski vs wysoki kontekst komunikacyjny, aktywność vs konserwatyzm, orientacja zewnętrzna vs wewnętrzna oraz status oparty na osiągnięciach vs na nadaniu.

W badaniach uczestniczyło 8 małych polskich przedsiębiorstw, które funkcjonują na zagranicznych rynkach. Do diagnozy kultury organizacyjnej przedsiębiorstw zastosowano badania ankietowe oparte na kwestionariuszu. Zawierał on pytania o przejawy wybranych wartości kulturowych. 71 respondentów odpowiadało na 32 określenia opisujące 8 analizowanych dychotomicznych wartości posługując się 5 stopniową skalą oceny natężenia występowania badanego zjawiska ( 1 - słabe, 5 - silne). Prezentacja wyników badań opiera się na średniej arytmetycznej obrazującej natężenie występowania badanych wartości kulturowych i ich aspektów.

\section{Kultura organizacyjna małych przedsiębiorstw prowadzących międzynarodową działalność - wyniki badań}

Uzyskane wyniki badań wskazują, że kultura organizacyjna badanych małych przedsiębiorstw działających na międzynarodowym rynku charakteryzuje się wieloma wartościami kulturowymi. Tworzą one specyficzne środowisko kulturowe opisane przez (wykres 1):

- nastawienie na zadania - 3,52;

- kolektywizm - 3,47;

- orientację na otoczenie - 3,45;

- niski kontekst komunikacyjny - 3,39;

- wysoką tolerancję niepewności - 3,21;

- status oparty na nadaniu $-3,16$;

- mały dystans władzy - 3,16;

- proaktywność $-2,95$. 
Wykres 1. Kultura organizacyjna małych przedsiębiorstw działających na międzynarodowym rynku

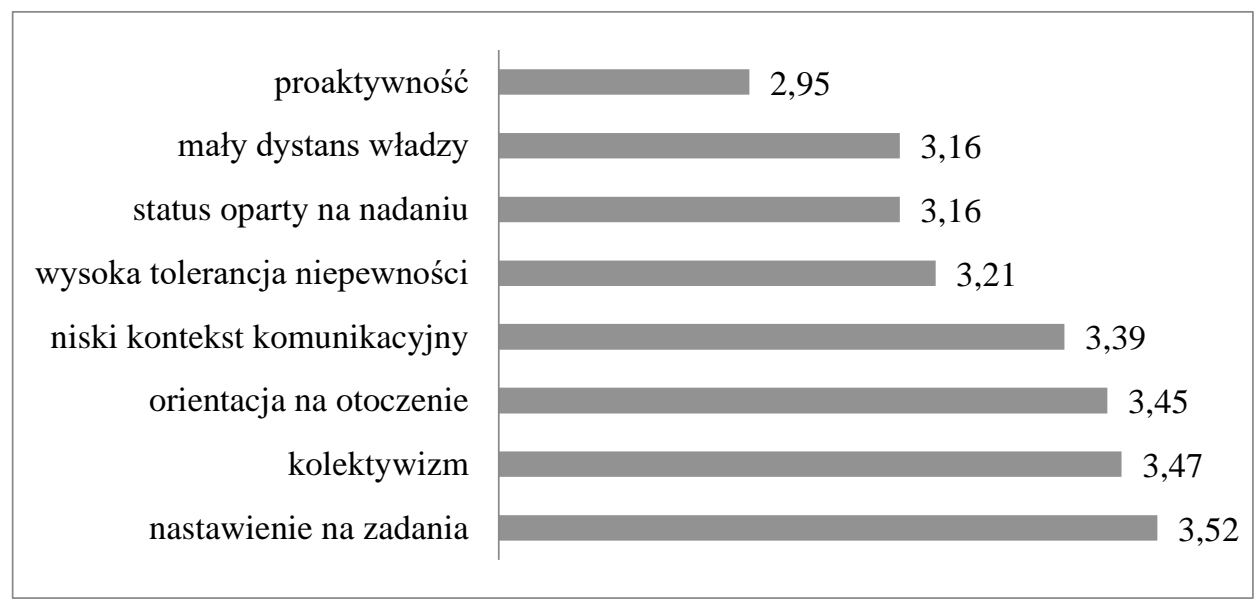

Źródło: opracowanie własne.

Zestawienie uzyskanych wyników w postaci podstawowych średnich opisowych oraz procentowego wskazania występowania wartości kulturowych przedstawia tabela 1.

Zidentyfikowania poszczególnych wartości kulturowych dokonano analizując przejawy poszczególnych wartości. Diagnoza nastawienia na ludzi i zadania została oparta na ocenie dobrego kierownika, stosunku do ludzi oraz kryterium sukcesu organizacji. Wyniki badań wskazują na występowanie zarówno przejawów nastawienia na ludzi, jak i na zadania, a natężenie ich można określić jako niewielkie. O priorytecie celów świadczy średnia świadomość rozpatrywania i mierzenia sukcesu przedsiębiorstwa w kategoriach ekonomiczno-finansowych $(4,15)$. O przeciwnym kierunku dowodzi natomiast postrzeganie dobrego kierownika, jako służącego radą i stwarzającego poczucie bezpieczeństwa, przy czym zjawisko to jest obserwowane ze średnim natężeniem $(3,99)$. Dwa inne przejawy wskazują na bardzo małe ich postrzeganie przez respondentów. Dotyczy to dbania o poprawne relacje międzyludzkie przez kierowników $(2,87)$, co przy tak niskiej ocenie świadczy o nastawieniu na zadania oraz nacisku na indywidualne zadania i wyniki $(2,90)$, to z kolei oznacza orientację na ludzi. Podsumowując otrzymane wyniki, można dostrzec podporządkowanie życia organizacyjnego, systemu i zasobów, w tym ludzkich, celom organizacji i priorytet wyników ekonomicznych, czyli dominację przejawów nastawienia na zadania. 
Tabela 1. Zestawienie odpowiedzi oraz statystyk opisowych wartości kulturowych

\begin{tabular}{|l|c|c|c|}
\hline \multirow{2}{*}{\multicolumn{2}{|c|}{ Wymiar kulturowy }} & \multicolumn{2}{c|}{ Ogólem } \\
\cline { 2 - 4 } & $\begin{array}{c}\text { \% } \\
\text { występowania }\end{array}$ & Średnia & Mediana \\
\hline Nastawienie na zadania & 71,8 & 3,52 & 3,5 \\
\hline Nastawienie na ludzi & 63,4 & 3,42 & 3,5 \\
\hline Indywidualizm & 63,4 & 3,40 & 3,5 \\
\hline Kolektywizm & 60,6 & 3,47 & 3,5 \\
\hline Mały dystans władzy & 59,2 & 3,16 & 3,5 \\
\hline Duży dystans władzy & 52,1 & 2,95 & 3,0 \\
\hline Orientacja na otoczenie & 53,5 & 3,45 & 3,0 \\
\hline Orientacja na wnętrze & 15,5 & 2,85 & 3,0 \\
\hline Niska tolerancja niepewności & 40,8 & 3,16 & 3,0 \\
\hline Wysoka tolerancja niepewności & 32,4 & 3,21 & 3,0 \\
\hline Proaktywność & 40,8 & 2,95 & 3,0 \\
\hline Konserwatyzm & 7,0 & 2,78 & 3,0 \\
\hline Status oparty na osiągnięciach & 40,8 & 3,08 & 3,0 \\
\hline Status oparty na nadaniu & 63,4 & 3,16 & 3,5 \\
\hline Niski kontekst komunikacyjny & 40,8 & 3,39 & 3,0 \\
\hline Wysoki kontekst komunikacyjny & 7,0 & 2,57 & 2,5 \\
\hline
\end{tabular}

Źródło: opracowanie własne.

Kolektywizm vs indywidualizm to kolejne badane wartości, które były oceniane na podstawie priorytetu jednostki nad grupą oraz stopnia rezygnacji z własnej niezależności ze względu na dobro grupy. Na podstawie wyników można sformułować spostrzeżenie o niewielkim natężeniu występowania przejawów indywidualizmu $(3,40)$ oraz kolektywizmu $(3,47)$. $\mathrm{W}$ badanych przedsiębiorstwach mało ceni się indywidualizm i jednostkową odpowiedzialność $(3,18)$. Pracownicy podejmują współpracę, ale nie rezygnują z własnej niezależności, przy czym zjawisko to obserwowane jest $\mathrm{z}$ niewielkim natężeniem $(3,63)$. Jednocześnie respondenci z podobnym natężeniem obserwują bezwzględną gotowość do współpracy przez pracowników $(3,42)$ kierujących się odpowiedzialnością za współpracowników, dążąc do harmonii i unikając konfliktów $(3,52)$. W ostatecznej ocenie można stwierdzić, że w badanych małych przedsiębiorstwach, prowadzących działalność na międzynarodowym rynku, przeważają przejawy kolektywizmu. 
Orientacja na otoczenie vs na wnętrze były diagnozowane poprzez badanie następujących ich przejawów: poczucie lojalności pracowników, tolerancja wobec odmiennych wartości oraz czy sprawy wewnętrzne, czy relacje $\mathrm{z}$ otoczeniem stanowią priorytet w organizacji. Posługując się wynikami badań można wnioskować o niewielkim występowaniu oznak orientacji zewnętrznej $(3,45)$ oraz bardzo małym $(2,85)$ wewnętrznej.

Widoczne jest dla respondentów priorytetowe traktowanie podmiotów zewnętrznych oraz dbanie o kontakty z nimi, ale skalę tego zjawiska ocenili jako niewielką $(3,51)$. Na podobnym, niewielkim poziomie $(3,41)$ obserwowana jest otwartość, szacunek i tolerancja pracowników wobec wartości z otoczenia. Uwaga kierownictwa skoncentrowana jest w bardzo małym stopniu na wewnętrznych sprawach $(2,75)$, co świadczy o nastawieniu na otoczenie. Identyczna interpretacja dotyczy kolejnego przejawu, a mianowicie identyfikowania się pracowników z przedsiębiorstwem. Badani zjawisko to ocenili na bardzo niskim poziomie $(2,97)$ co oznacza orientację na otoczenie. Podsumowując, kultura organizacyjna małych przedsiębiorstw funkcjonujących na międzynarodowym rynku jest nastawiona na otoczenie.

Do identyfikacji niskiego vs wysokiego kontekstu komunikacyjnego posłużono się opinią respondentów na temat przewagi werbalnego formułowania wypowiedzi nad niewerbalnym komunikowaniem się. Badani $\mathrm{z}$ niewielkim natężeniem postrzegali przejawy niskiego kontekstu komunikacyjnego $(3,39)$ oraz z bardzo małym - wysokiego $(3,22)$, co może wręcz świadczyć o ich braku. Wśród tych pierwszych znalazło się ocenione na średnim poziomie zdobywanie i przekazywanie informacji w drodze bezpośredniej rozmowy (3,96). O niskim kontekście komunikacyjnym świadczy także bardzo małe natężenie wysokokontekstowego przejawu drugiego sedna wypowiedzi $(2,49)$ i używania intuicji w rozmowie $(2,65)$. Z kolei fakt, że zdaniem respondentów większość pracowników nie wyraża otwarcie i bezpośrednio swoich myśli przemawia za wysokim kontekstem komunikacyjnym $(2,83)$. Reasumując, w badanych małych przedsiębiorstwach stosowana jest komunikacja niskokontekstowa.

Ocena wysokiego vs niskiego unikania niepewności została oparta na następujących przejawach: znaczenie reguł i procedur, elastyczność działania, skłonność do ryzyka oraz stosunek do pracy. Analizując wyniki badań na ten temat można stwierdzić, że w małych przedsiębiorstwach działających na międzynarodowym rynku $\mathrm{z}$ niewielkim natężeniem badani obserwują zarówno objawy unikania niepewności $(3,49)$, jak i jej tolerowania $(3,43)$. Uszczegóławiając ten wynik można wskazać powszechność istnienia reguł, praktyk postępowania, przy czym skala tego zjawiska jest niewielka $(3,30)$. $\mathrm{Z}$ drugiej strony respondenci w iden- 
tycznym stopniu obserwują elastyczność pracowników w stosowaniu reguł i dostosowywaniu ich do okoliczności $(3,34)$. W parze z taką postawą idzie skłonność pracowników do ryzyka $(3,10)$. Jest ona jednak oceniona bardzo nisko. Etos pracy postrzegany jest na małym poziomie $(3,04)$. W ostatecznej ocenie, kulturę organizacyjną, badanych małych przedsiębiorstw, można scharakteryzować jako kulturę o wysokiej tolerancji niepewności.

Status oparty na nadaniu vs osiągnięciach został zdiagnozowany na podstawie kryteriów awansowania i szacunku wobec kierownika. Uzyskane wyniki badań wskazują na małe natężenie zarówno przejawów kultury ceniącej dokonania pracownika $(3,06)$, jak i opierającej się na kryteriach hierarchii i stażu $(3,16)$. Pozycja w hierarchii organizacyjnej jest podstawą szacunku wobec przełożonego, przy czym skala tego zjawisko jest niewielka $(3,72)$. Pozycja pracownika w przedsiębiorstwie W opinii respondentów zależy od jego kompetencji $(3,08)$ oraz oceny jego rozwoju $(3,04)$. Obydwa przejawy są jednak postrzegane z małym natężeniem. Bardzo małe wskazanie $(2,62)$ uzyskał przejaw obrazujący awans z tytułu stażu pracy, co świadczy o statusie opartym na osiągnięciach. Kulturę organizacyjną małych przedsiębiorstw, działających na zagranicznych rynkach, w końcowej ocenie charakteryzuje status oparty na nadaniu.

Kolejną badaną wartością był mały vs duży dystans władzy. Diagnozę jej oparto na rozpatrywaniu charakteru relacji między kierownictwem a podwładnymi. Wyniki badań pozwalają stwierdzić dominację przejawów egalitaryzmu $(3,16)$ nad hierarchią $(2,95)$. Świadczy o tym dodatkowo bardzo małe wskazanie występowania oznak dużego dystansu władzy. Za kulturą małego dystansu władzy przemawia postrzegany z niewielkim natężeniem koleżeński, otwarty na kontakty stosunek przełożonych do podwładnych $(3,44)$. Z kolei, mimo małej skali $(3,08)$, ocena przez respondentów istnienia dystansu władzy wskazuje na hierarchię. Interpretując wyniki badań trudno jednoznacznie wnioskować o poziomie dystansu władzy na podstawie poziomu poczucia podporządkowania. $\mathrm{Z}$ bardzo małym natężeniem badani oszacowali zarówno nieprzenoszenie zależności służbowych poza miejsce pracy $(2,90)$, jak i odwrotną sytuację, czyli przenoszenie zależności służbowej poza miejsce pracy $(2,83)$. Podsumowując, można stwierdzić, że kulturę organizacyjną badanych małych przedsiębiorstw opisuje mały dystans władzy.

Diagnoza proaktywności vs konserwatyzmu opierała się na opinii badanych na temat stopnia aktywności pracowników, traktowania zmiany jako szansy czy zagrożenia oraz roli tradycji w funkcjonowaniu przedsiębiorstwa. Wyniki badań wskazują na bardzo małe występowanie przejawów zarówno kultury proaktywnej $(2,95)$, jak i konserwatywnej $(2,78)$. 
Rezultat ten ukształtowała bardzo mała ocena roli tradycji w podejmowanych decyzjach i działaniach $(2,82)$ oraz pasywnej postawy pracowników $(2,76)$. Jednocześnie, $z$ bardzo małym nasileniem, badani postrzegają pracowników jako osoby aktywne, chętnie podejmujące inicjatywę $(2,86)$, którzy szybkie zmiany postrzegają jako szansę dla organizacji $(3,04)$. Ostatecznie, można stwierdzać, że kultura organizacyjna innowacyjnych przedsiębiorstw charakteryzuje się proaktywnością.

\section{Podsumowanie}

Zidentyfikowana kultura organizacyjna stanowi zbiór wartości najbardziej charakteryzujących badane przedsiębiorstwa i najsilniej postrzeganych przez badanych, są to: nastawienie na zadania, kolektywizm, orientacja na otoczenie, niski kontekst komunikacyjny, wysoka tolerancja niepewności, status oparty na nadaniu, mały dystans władzy oraz proaktywność. Niektóre z tych wartości się uzupełniają, inne z kolei wykluczają. W rezultacie prezentują podstawę myślenia i działania pracowników małych przedsiębiorstw działających na międzynarodowym rynku. Oznacza to, że pracownicy zorientowani są zadaniowo na otoczenie. W swojej zadaniowości wykazują aktywność wobec nowych wartości i sposobów ich realizacji nie unikając niejednoznacznych i niepewnych sytuacji. Wolą pracować w grupie i kierują się wspólnym interesem. Kontaktom z zewnętrznymi podmiotami oraz zespołowości sprzyja preferencja słownego, bezpośredniego komunikowania się oraz mały dystans władzy.

Zidentyfikowana kultura organizacyjna badanych przedsiębiorstw stanowi specyficzne środowisko kulturowe, które może osłabiać bądź wzmacniać ich funkcjonowanie na zagranicznych rykach. Najsilniej manifestowane jest nastawienie na zadania. Podporządkowanie pracownika, jego miejsca w strukturze, czynności i oceny pracy, wynikom o charakterze ekonomicznym związanych z działalnością na rynkach obcych mocno kształtuje świadomość priorytetu w organizacji. Wartość ta sprzyja internacjonalizacji badanych przedsiębiorstw. W dużym stopniu zachowania pracowników kształtuje także kolektywizm oraz orientacja na otoczenie. Wymienione wartości korespondują z nastawieniem na zadania, bowiem kultura zadaniowa charakteryzuje się orientacją na klienta oraz współpracą. Pracownicy, badanych przedsiębiorstw, pracują w środowisku ukierunkowanym zadaniowo na zagranicznego klienta opierając się na zespołowości i współpracy z podmiotami polskimi i obcymi. Niski kontekst komunikacyjny jest kolejną istotną wartością kulturową $\mathrm{w}$ badanych przedsiębiorstwach. Jest ona powiązana $\mathrm{z}$ orientacją na oto- 
czenie i relacja ta może mieć wspierający charakter, ale tylko w przypadku prowadzenia działalności gospodarczej w krajach preferujących komunikaty werbalne i bezpośredniość wypowiedzi. W kontaktach rynkowych z podmiotami reprezentującymi kultury wysokokontekstowe ta cecha kulturowa może stanowić dla badanych przedsiębiorstw poważną barierę. Niski kontekst komunikacyjny negatywnie koreluje także z kolektywizmem. W kulturach kolektywistycznych fakt obcowania $\mathrm{z}$ innymi jest ważniejszy niż prowadzenie rozmowy. W związku z powyższym preferencja dla przekazywania informacji w formie komunikatu werbalnego może, w badanych przedsiębiorstwach, ograniczać współpracę. Wysoka tolerancja niepewności, charakteryzująca badane przedsiębiorstwa, to kolejna wartość w swojej istocie wspierająca ich umiędzynarodowienie działalności gospodarczej. Stanowi bowiem ogromne wyzwanie dla przedsiębiorstw, niesie w sobie ryzyko i niepewność. Dlatego wykazywanie przez pracowników dużej tolerancji dla nowych sytuacji i wyzwań, ułatwia funkcjonowanie na odmiennych rynkach. Pozytywnie z niskim unikaniem niepewności koreluje kolejna zidentyfikowana wartość kulturowa, jaką jest mały dystans władzy. Pracownicy wysoko tolerujący niepewność mają silnie rozwinięte poczucie samokontroli, samodecydowania, odgrywania różnych ról, co niewątpliwie jest możliwe w środowisku realizującym demokratyczne wartości. Taki wyróżnik małego dystansu władzy jak partnerskie traktowanie uczestników rozmów biznesowych, niezależnie od ich narodowości, sprzyja prowadzeniu międzynarodowej działalności gospodarczej. Kolejna, charakteryzująca badane przedsiębiorstwa, wartość kulturowa jaką jest status oparty na nadaniu, nie wspiera procesu internacjonalizacji. Ocena działania pracownika opierająca się na takich czynnikach jak: płeć, wiek, formalne wykształcenie, zamiast na jego dokonaniach związanych z wykonywanymi zadaniami, nie pobudza jego zainteresowania i zaangażowania w realizację wyników przedsiębiorstwa. Proaktywność jest kolejną wartością kulturową, która ma pozytywne skojarzenie z prowadzeniem działalności gospodarczej międzynarodowej i charakteryzuje badane przedsiębiorstwa. Oznacza ona bowiem otwartość na nowe rozwiązania, gotowość do podejmowania ryzyka, uczenia się i zmian. Wartość ta koreluje z wysoką tolerancją niepewności.

Charakterystyczne dla badanych przedsiębiorstw wartości kulturowe występują z różnym natężeniem. Można więc wyłonić te, które w większym stopniu od innych wpływają na zachowania pracowników, w tym związane z ekspansją gospodarczą na międzynarodowych rynkach. Najsilniej oddziałuje na nich nastawienie na zadania, jego okazywanie jest jednak niewielkie. Wysokie miejsce dotyczy także kolektywizmu, orien- 
tacji zewnętrznej oraz niskiego kontekstu komunikacyjnego, które manifestowane są z niewielkim natężeniem. Kolejną pozycję zajmują wysokie unikanie niepewności, mały dystans władzy oraz status oparty na nadaniu, które to cechy w niskim stopniu zostały rozpoznane w badanych organizacjach. Najsłabiej pracownicy wykazują aktywność. Żadna ze zidentyfikowanych wartości kulturowych nie była z bardzo dużym, dużym, ani średnim natężeniem postrzegana przez respondentów.

Ostatecznie można stwierdzić, że w badanych przedsiębiorstwach zauważalne są różne przejawy wartości kulturowych. Część z nich tworzy sprzyjające działalności międzynarodowej warunki kulturowe, wśród nich są: nastawienie na zadania, wysoka tolerancja niepewności, proaktywność, orientacja na otoczenie, mały dystans władzy, a opcjonalnie także kolektywizm i niski kontekst komunikacyjny. Niestety ich okazywanie jest słabe, a często bardzo słabe. Przy tak niskiej ocenie występowania wartości w życiu organizacyjnym można stwierdzić, że kultura organizacyjna $\mathrm{w}$ niewielkim stopniu wspiera międzynarodową działalność badanych przedsiębiorstw. Są one zbyt słabo upowszechnione i zakorzenione w świadomości pracowników. Stanowią jednak potencjalne pozytywne środowisko kulturowe dla ekspansji gospodarczej badanych przedsiębiorstw.

\section{BIBLIOGRAFIA}

Daszkiewicz N. (2004), Internacjonalizacja matych i średnich przedsiębiorstw we wspótczesnej gospodarce, Gdańsk.

Griffin R.W., Pustay M.W. (1995), International Business, Addison Wesley, New York.

Mead R., Andrews T.G. (2011), Zarządzanie międzynarodowe, Wolters Kluwer Polska SA, Warszawa.

Nieżurawski L., Nieżurawska J. (2013), Wybrane przyczyny sukcesu i porażek internacjonalizacji przedsiębiorstw, „Zarządzanie i Finanse”, nr 4/2.

Polska Agencja Wspierania Przedsiębiorczości (2014), Raport końcowy. Ewaluacja potencjatu eksportowego przedsiębiorstw w Polsce, Wydawnictwo PARP, Warszawa.

Rothlauf J. (2010), Rozważania na temat zarzadzania międzykulturowego, [w:] Krzykała-Schaefer R. (red.), Zarzadzanie międzykulturowe w jednoczacej się Europie, Wydawnictwo Wyższej Szkoły Bankowej, Poznań.

Rozkwitalska M. (2011), Bariery w zarządzaniu międzykulturowym. Perspektywa filii zagranicznych korporacji transnarodowych, Wolters Kluwer Polska SA, Warszawa.

Winkler R. (2007), Bariery internacjonalizacji organizacji, „Zeszyty Naukowe Akademii Ekonomicznej w Krakowie”, z. 747.

Wójcik Ł. (2013), Internacjonalizacja i jej bariery. POIR 2014-2020, „Paszport do eksportu", http://paszportdoeksportu.pl/frontpage-article/internacjonalizacja-i-jej-bariery-poir-2014-2020, [dostęp: 25.08.2016]. 


\section{ORGANIZATIONAL CULTURE OF SMALL BUSINESSES OPERATING ON THE INTERNATIONAL MARKET}

\section{ABSTRACT}

The paper presents research results aiming to identify organisational culture of businesses operating internationally.

The diagnosis of the organizational culture was based upon cultural values. In order to analyse and describe the organizational culture of the studied businesses a survey questionnaire was applied. The study encompassed 8 Polish companies and 71 employees.

Research results indicate that the organizational culture of businesses operating internationally is characterized by focus on tasks, collectivism, focus on the surrounding environment, high tolerance of insecurity, status based on bestowal, small distance of authority, and activity. Cultural values are generally manifested with low intensity, which may constitute a proof of weak organizational culture.

Keywords: organizational culture, small enterprises, international market. 